\title{
Profilowanie rybosomów jako innowacyjne narzędzie do badania procesu syntezy białek
}

\begin{abstract}
STRESZCZENIE
$\mathrm{T}$ echnika profilowania rybosomów (Ribo-seq) jest obecnie najefektywniejszą metodą badania procesu syntezy białek $w$ warunkach in vivo. Ribo-seq polega na sekwencjonowaniu fragmentów mRNA ochranianych przez rybosomy (tzw. odcisków rybosomów), co pozwala na określenie dokładnej pozycji rybosomów na transkryptach. Zaawansowana analiza bioinformatyczna danych uzyskanych z sekwencjonowania umożliwia selekcję odcisków rybosomów pochodzących od translatujących rybosomów, dając informację o rzeczywistym statusie translacyjnym mRNA. Celem artykułu jest zapoznanie czytelników $\mathrm{z}$ metodą profilowania rybosomów oraz podstawowymi strategiami eksperymentalnymi i bioinformatycznymi, istotnymi w uzyskaniu satysfakcjonujących rezultatów. Ponadto artykuł przedstawia konkretne przykłady zastosowania techniki profilowania rybosomów w różnych systemach biologicznych, dając znaczący wgląd w proces translacji i jego regulację.
\end{abstract}

\section{WPROWADZENIE}

Proces translacji jest kluczowym elementem życia komórki, w którym na bazie informacji genetycznej zawartej w mRNA produkowane są białka. Synteza białek składa się z kilku etapów, a każdy z nich wymaga precyzyjnego działania wielu elementów, które znajdują się pod stałą kontrolą ze względu na konieczność adaptacji organizmów do zmieniających się warunków otoczenia oraz dostosowywania ich metabolizmu do określonych etapów życia oraz rozwoju. Zasadniczą rolę w syntezie białek odgrywają białkowo-rybonukleinowe kompleksy zwane rybosomami. Przez dekady panował pogląd, że rybosomy to struktury homogenne, niezmienne pod względem składu oraz funkcji. Jednakże w ostatnich latach pojawiła się hipoteza tzw. wyspecjalizowanych rybosomów, zakładająca istnienie w komórce subpopulacji rybosomów różniących się składem i zdolnościami do translacji określonych mRNA [1-4]. Istnienie wyspecjalizowanych rybosomów w komórce to tylko jeden $\mathrm{z}$ możliwych sposobów regulacji translacji. Synteza białek może być również regulowana poprzez czynniki działające $\mathrm{w}$ konfiguracji cis oraz trans [5,6]. Elementy cis to specyficzne sekwencje występujące najczęściej w regionach UTR (ang. untranslated regions), natomiast czynnikami trans mogą być białka, małe RNA czy też metabolity, które poprzez wiązanie się do elementów cis mogą wpływać na translację.

Badanie procesu syntezy białka oraz czynników, które odpowiadają za jego regulację było dotychczas utrudnione ze względu na brak odpowiednich narzędzi. Dopiero opracowanie innowacyjnej metody profilowania rybosomów (Ribo-seq, ang. ribosome profiling) pozwoliło na wysokorozdzielcze badanie procesu translacji w skali całego genomu [7]. Profilowanie rybosomów oparte jest na sekwencjonowaniu nowej generacji (NGS, ang. next generation sequencing) krótkich fragmentów mRNA chronionych przez rybosomy (RFs, ang. ribosomal footprints), otrzymanych dzięki działaniu specyficznej nukleazy (Ryc. 1). Olbrzymią zaletą tej techniki jest możliwość monitorowania translacji in vivo poprzez precyzyjne zmapowanie pozycji rybosomu na transkrypcie. Równolegle z techniką profilowania rybosomów wykonuje się wysokoprzepustowe sekwencjonowanie całkowitego RNA (RNA-seq), poddanego uprzednio przypadkowej fragmentacji $w$ celu uzyskania fragmentów o wielkości porównywalnej z wielkością fragmentów mRNA chronionych przez rybosomy. Na podstawie analiz porównawczych danych z Ribo-seq i RNA-seq możliwe jest określenie na jakim poziomie dochodzi do regulacji ekspresji genów (Ryc. 2). Równomierne zwiększenie ilości mRNA (RNA-seq) oraz syntezy białka (Ribo-seq) świadczy o transkrypcyjnej indukcji ekspresji genów, podczas gdy zwiększenie syntezy białka (Ribo-seq) bez zmian w ilości mRNA (RNA-seq) świadczy o translacyjnej indukcji ekspresji genów.

\section{Urszula Kaźmierczak}

\section{Małgorzata Kwaśniak-Owczarek ${ }^{\bowtie}$}

Wydział Biotechnologii, Uniwersytet Wrocławski, Wrocław

$\llbracket$ Wydział Biotechnologii, Uniwersytet Wrocławski, ul. F. Joliot-Curie 14A, 50-383 Wrocław; tel.: (71) 375 6297, e-mail: malgorzata kwasniak-owczarek@uwr.edu.pl

Artykuł otrzymano 23 listopada 2018 r. Artykuł zaakceptowano 10 stycznia 2019 r.

https://doi.org/10.18388/pb.2019_255

Słowa kluczowe: profilowanie rybosomów, translacja, rybosom, ekspresja genów, sekwencjonowanie nowej generacji

Wykaz skrótów: CDS (ang Coding Sequence) - sekwencja kodująca; NGS (ang. Next-Generation Sequencing) - sekwencjonowanie nowe generacji; ORF (ang. Open Reading Frame) otwarta ramka odczytu; PO (ang. P-site Offset) - przesunięcie miejsca P względem odcisku rybosomalnego; RF (ang. ribosome footprint) - odcisk rybosomu; Ribo-seq (ang. Ribosome profiling) - profilowanie rybosomów; RNA-seq (ang. RNA sequencing) - sekwencjonowanie RNA; UTR (ang. untranslated regions) - rejon mRNA nieulegający translacji

Podziękowania: Badania prowadzone przez autorów niniejszej pracy przeglądowej finansowane są ze środków na naukę przyznanych przez Narodowe Centrum Nauki na realizacje projektu badawczego OPUS8: 2014/15/B/ NZ2/01065. 
A)

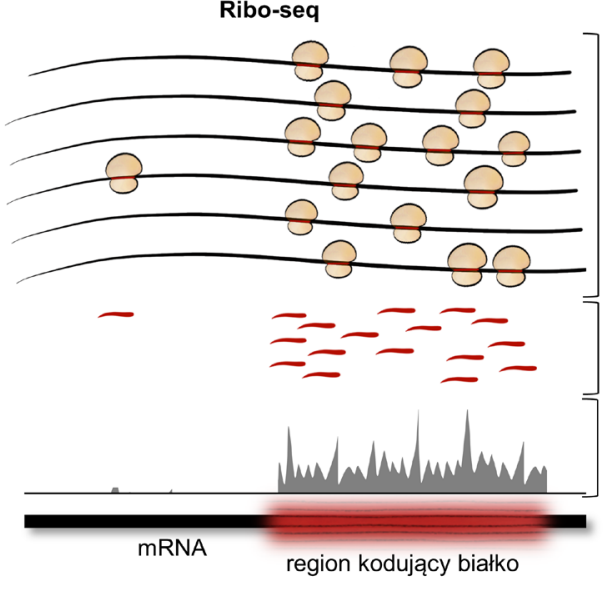

B)

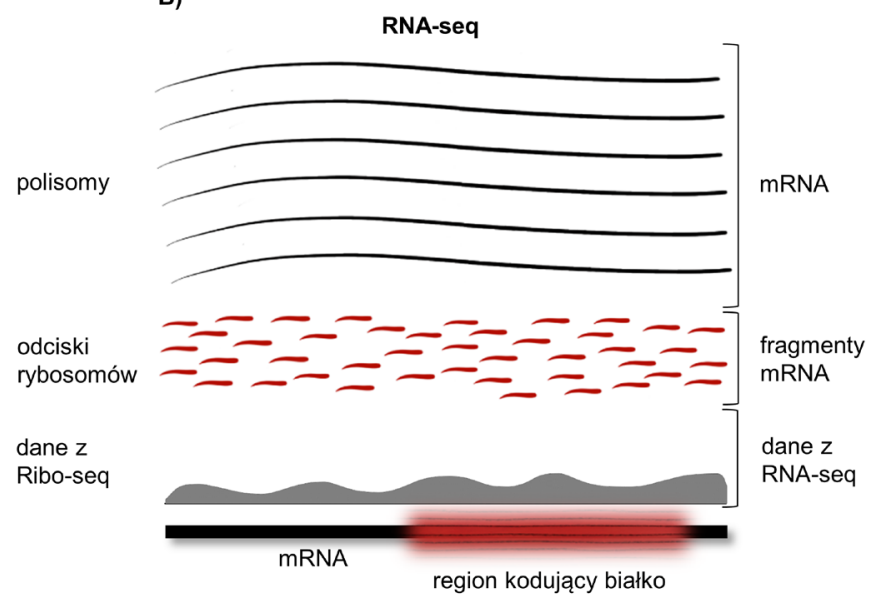

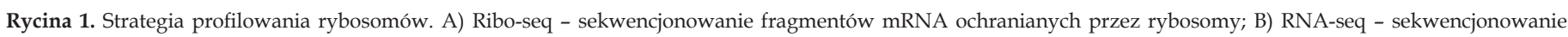
fragmentów całkowitego mRNA (RNA-seq). Rysunek opracowano wg [14].
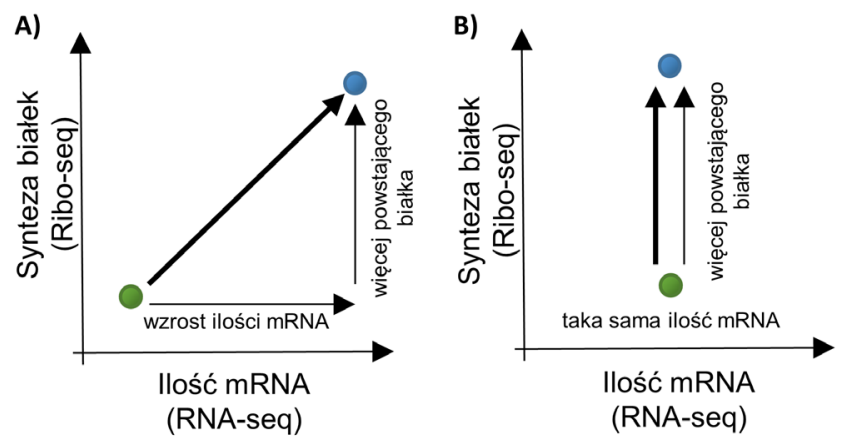

Rycina 2. Poziomy regulacji indukcji ekspresji genów na podstawie porównania danych z Ribo-seq i RNA-seq. A) Transkrypcyjna indukcja ekspresji genów; B) Translacyjna indukcja ekspresji genów. Rysunek opracowano wg [7].

Profilowanie rybosomów może dostarczyć różnorodnych informacji dotyczących procesu translacji, jednakże wymaga zastosowania odpowiedniej strategii eksperymentalnej. Niniejsza praca stanowi zwięzłe opracowanie metodologii i zastosowania profilowania rybosomów w badaniu translacji, z zaznaczeniem szczegółów istotnych z punktu widzenia planowania i wykonywania eksperymentu. Praca opisuje kolejne etapy procedury Ribo-seq, analizy bioinformatycznej uzyskanych danych, jak również dostarcza istotnych informacji o procesie translacji i jego regulacji w oparciu o zastosowanie techniki profilowania rybosomów.

\section{IZOLACJA FRAGMENTÓW mRNA CHRONIONYCH PRZEZ RYBOSOMY ORAZ PRZYGOTOWANIE I SEKWENCJOWANIE BIBLIOTEK OTRZYMANYCH FRAGMENTÓW}

Zasadniczym etapem $\mathrm{w}$ metodzie profilowania rybosomów jest uzyskanie fragmentów chronionych przez rybosomy. W zależności od rodzaju materiału badawczego, badanego etapu translacji lub innych potrzeb wynikających ze specyfiki eksperymentu, istotne jest odpowiednie dostosowanie każdego etapu izolacji tych fragmentów. Otrzymane odciski rybosomów wykorzystywane są do przygotowania bibliotek cDNA, które następnie są sekwencjonowane. Ze względu na niewielką długość otrzymywanych odcisków rybosomów do przygotowania ich bibliotek zaadoptowano i zoptymalizowano podejście wykorzystywane przy tworzeniu bibliotek do sekwencjonowania cząsteczek mikroRNA (ang. microRNA-seq) [8,9]. W poniższych podrozdziałach opisane zostały szczegółowo etapy otrzymania odcisków rybosomów, przygotowania bibliotek cDNA oraz ich sekwencjonowania $\mathrm{w}$ metodzie profilowania rybosomów. Poszczególne etapy są schematycznie przedstawione na rycinie 3.

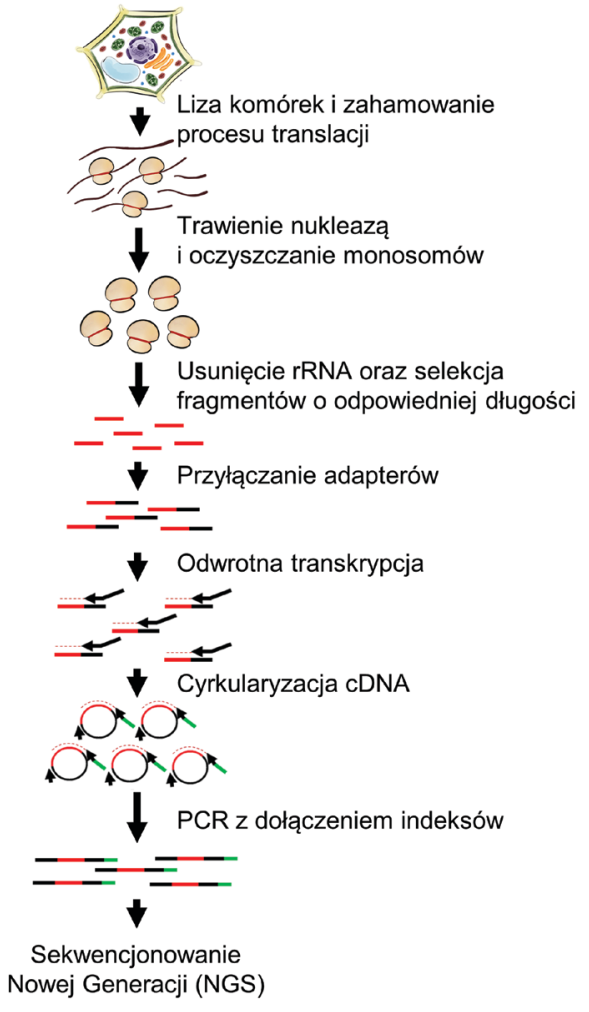

Rycina 3. Schemat przedstawiający główne etapy izolacji fragmentów mRNA chronionych przez rybosomy oraz przygotowania bibliotek tych fragmentów do sekwencjonowania (Ribo-seq). 
LIZA KOMÓREK ORAZ ZAHAMOWANIE PROCESU TRANSLACJI

Monitorowanie procesu translacji w warunkach in vivo wymaga uzyskania dostępu do rybosomów oraz związanych z nimi mRNA poprzez odpowiednie zdezintegrowanie całych komórek lub organelli (mitochondriów, chloroplastów). Istotne znaczenie w uzyskaniu jak najlepszej rozdzielczości otrzymywanych odcisków rybosomów ma dobranie odpowiedniego buforu do lizy [10]. Początkowo do tego celu wykorzystywano bufory charakteryzujące się wysoką siłą jonową oraz pojemnością buforową [11-13]. Wykazano jednakże, że duża siła jonowa posiada hamujący wpływ na aktywność rybonukleazy, niezbędnej do otrzymania odcisków rybosomów, w związku z czym aktualnie zaleca się, aby bufory do lizy charakteryzowały się niską siłą jonową oraz pojemnością buforową [10]. Kluczowym wyzwaniem metodologicznym w profilowaniu rybosomów jest szybkie i skuteczne zahamowanie procesu translacji, tak aby uchwycić rybosomy w badanym stanie fizjologicznym [14]. W tym celu już podczas hodowli komórek, jak również podczas ich lizy dodaje się inhibitory translacji, których zadaniem jest „zamrożenie” rybosomów na transkrypcie i uniemożliwienie dalszej elongacji poprzez hamowanie aktywności peptydylotransferazowej [15]. Do zahamowania translacji cytoplazmatycznej najczęściej wykorzystuje się cykloheksymid [9], natomiast w przypadku translacji mitochondrialnej i chloroplastowej używa się chloramfenikolu [16]. Należy jednak pamiętać, że w przypadku stosowania tych inhibitorów inicjujące rybosomy mogą rozpoczynać i kontynuować syntezę białek aż do momentu napotkania inhibitora, co w konsekwencji skutkuje nagromadzeniem się odczytów w obrębie miejsca rozpoczęcia translacji. Zminimalizowanie tego efektu jest możliwe poprzez zastosowanie wyższego stężenia inhibitora [17]. Alternatywnym sposobem zatrzymania rybosomów na etapie elongacji jest szybkie mrożenie komórek/ekstraktów komórkowych w ciekłym azocie. Z kolei, aby zablokować rybosomy zaangażowane $\mathrm{w}$ inicjację translacji podczas lizy komórek dodawane są związki chemiczne, tj. harringtonina lub laktimidomycyna, które nie zaburzając etapu elongacji prowadzą do unieruchomienia inicjujących rybosomów [18]. Podobny efekt można uzyskać stosując cykloheksymid po uprzednim dodaniu puromycyny, wywołującej przedwczesne zakończenie translacji [19]. Zablokowanie inicjujących rybosomów pozwala na identyfikację nowych, niekanonicznych miejsc inicjacji translacji oraz ułatwia określenie miejsca $\mathrm{P}$ rybosomu względem związanego w nim fragmentu mRNA (tzw. pozycjonowanie rybosomu) [9].

\section{TRAWIENIE NUKLEAZA \\ I OCZYSZCZANIE MONOSOMÓW}

Trawienie nukleazą jest krytycznym etapem wymaganym do otrzymania dobrej jakości odcisków rybosomów, w którym dochodzi do wytrawienia nieochranianych przez rybosom fragmentów mRNA. Biorąc pod uwagę fakt, że rybosomy składają się nie tylko z białek, ale również z rRNA dobranie odpowiedniego enzymu jest zasadnicze. Nukleaza powinna zdegradować niechronione przez rybosom fragmenty mRNA, jednocześnie nie trawiąc cząsteczek rRNA, zapewniając tym samym integralność rybosomów [20]. Odpowiednio dobrana nukleaza powinna także zapewniać całkowitą konwersję polisomów do monosomów. W przypadku profilowania rybosomów bakteryjnych początkowo stosowano mikrokokalną nukleazę (tzw. MNazę), która nie wytrawia w znaczący sposób rRNA, ale niestety wykazuje silne preferencje nukleotydowe, co prowadzi do ograniczenia rozdzielczości uzyskiwanych odcisków, a otrzymane dane wymagają bardziej skomplikowanej analizy bioinformatycznej. W systemach eukariotycznych głównie stosowaną rybonukleazą jest RNAza I z E. coli, która nie wykazuje preferencji do rozpoznawania określonych sekwencji, dzięki czemu pozwala na uzyskanie szerokiego spektrum odcisków rybosomów [9]. Analiza porównawcza działania różnych RNaz: I, A, S7 i T1 przeprowadzona przez Gerashchenko i Gladysheva (2017) sugeruje, że rybosomy pochodzące $\mathrm{z}$ różnych organizmów wykazują zróżnicowaną tolerancję na działanie różnych rybonukleaz. Testując cztery wymienione wyżej RNazy u drożdży i myszy pokazano znaczący wpływ użytej rybonukleazy na pokrycie poszczególnych transkryptów przez rybosomy. Ponadto wykazano, że rybonukleaza T1 jest jedynym enzymem, który skutecznie przekształca polisomy do monosomów, jednocześnie nie zaburzając integralności rybosomów, w bakteriach, nicieniach i muszkach owocowych [20].

Kolejnym krokiem po wytrawieniu fragmentów mRNA nieochranianych przez rybosom jest izolacja monosomów, w których wnętrzu znajdują się odciski rybosomów. W tym celu w zależności od organizmu lub organellum $\mathrm{z}$ jakiego izoluje się monosomy najczęściej stosuje się odpowiednie wirowanie w gradiencie sacharozowym [9]. Inną alternatywą uzyskania frakcji monosomów jest metoda filtracji żelowej, wykorzystująca różną zdolność penetracji ziaren żelu w zależności od wielkości cząsteczek [21]. Zanieczyszczenia innymi dużymi kompleksami nukleoproteinowymi można zminimalizować poprzez oczyszczanie kompleksów rybosomalnych wyznakowanych znacznikiem epitopowym (np. FLAG-tag, Strep-tag) z zastosowaniem chromatografii powinowactwa [22,23].

\section{USUNIECIE rRNA I SELEKCJA FRAGMENTÓW O ODPOWIEDNIEJ DŁUGOŚCI}

Następnie uzyskane preparaty oczyszcza się od rRNA, aby podczas sekwencjonowania zminimalizować liczbę odczytów niepochodzących od ochranianych przez rybosomy fragmentów mRNA. W tym celu wykorzystuje się dostępne na rynku komercyjne zestawy odczynników albo samodzielnie projektuje się sondy komplementarne do odpowiednich cząsteczek rRNA. Zastosowanie sond wyznakowanych biotyną umożliwia oczyszczenie preparatów za pomocą chromatografii powinowactwa z użyciem streptawidyny [9]. Alternatywnie można wykorzystać system wykorzystujący kulki magnetyczne opłaszczone streptawidyną, które wiążą się do biotynolowanych sond oligonukleotydowych rozpoznających cząsteczki rRNA i umożliwiają w ten sposób ich usunięcie [24,25].

Niedotrawione przez nukleazę fragmenty mRNA mogą zostać wykorzystane do stworzenia bibliotek fragmentów odcisków rybosomów i tym samym generować fałszywe odczyty. Aby usunąć powyższe sekwencje preparaty rozdziela się w elektroforezie w warunkach denaturujących w żelu poliakrylamidowym, po której wycina się z żelu 
fragmenty RNA odpowiadające wielkości fragmentów ochranianych przez rybosom. W zależności od organizmu, jak również kompartymentu komórki, w którym badamy proces translacji, wielkość fragmentów mRNA chronionych przez rybosomy jest zróżnicowana i może wahać się od 26 do 34 pz dla organizmów eukariotycznych i od 20 do 40 pz dla organizmów prokariotycznych [26-29].

\section{TWORZENIE BIBLIOTEK cDNA I ICH SEKWENCJONOWANIE}

W dalszym etapie na bazie otrzymanych odcisków rybosomów tworzy się biblioteki cDNA. W przypadku profilowania rybosomów przygotowuje się biblioteki specyficzne wobec nici (ang. strand-specific), co umożliwia późniejsze zidentyfikowanie, z której nici DNA, kodującej (+) czy też niekodującej (-), pochodzi dany odcisk. Aby uniknąć wybiórczego sekwencjonowania odczytów do końców 3' wyizolowanych odcisków rybosomów dodaje się tzw. adaptery (poliadenylowane oligonukleotydy) [30]. Przyłączone adaptery służą następnie do przeprowadzenia reakcji odwrotnej transkrypcji, czyli przepisania otrzymanych odcisków rybosomów na cDNA. Otrzymane cDNA oczyszcza się za pomocą elektroforezy w żelu poliakrylamidowym i przeprowadza się cyrkularyzację pierwszej nici cDNA. Następnie za pomocą reakcji PCR z wykorzystaniem starterów komplementarnych do sekwencji znajdującej się wewnątrz adapterów amplifikuje się biblioteki. Zastosowanie odpowiednich starterów z dołączonymi dodatkowo sekwencjami, tzw. indeksami, umożliwia wyznakowanie bibliotek, pozwalając na jednoczesne sekwencjonowanie kilku prób na raz. Do sekwencjonowania bibliotek najczęściej wykorzystuje się technologię opracowaną przez firmę Illumina (https://www.illumina.com/), czyli sekwencjonowanie mostkowe oparte o syntezę de novo nici komplementarnej z odwracalną terminacją [31]. Sekwencjonowanie w zależności od potrzeb, a sw szczególności wymaganej głębokości sekwencjonowania, można przeprowadzić w aparatach typu MiSeq, NextSeq oraz HighSeq.

\section{ANALIZA BIOINFORMATYCZNA DANYCH UZYSKANCYH Z RIBO-SEQ}

Sekwencjonowanie bibliotek generuje miliony odczytów, których analiza nie byłaby możliwa bez zastosowania odpowiednich strategii oraz narzędzi bioinformatycznych. Nawet odpowiednie przygotowanie bibliotek nie pozwala na pozbycie się wszystkich fałszywych odczytów, niepochodzących od translatujących rybosomów. Stąd też, dane po sekwencjonowaniu należy poddać szeregowi opisanych poniżej obróbek bioinformatycznych. Poszczególne kroki analizy bioinformatycznej są schematycznie przedstawione na rycinie 4 .

\section{FILTRACJA I USUWANIE ZANIECZYSZCZEŃ}

Pierwszym krokiem analizy bioinformatycznej danych otrzymanych z sekwencjonowania jest usunięcie odczytów o słabej jakości. Do tego celu najczęściej używa się oprogramowania FastX-toolkit (http://hannonlab.cshl.edu/fastx_ toolkit/). W bibliotece często odczyty składają się nie tylko z właściwych sekwencji, ale również z adapterów, których
Generacja odczytów

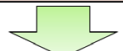

Odcięcie sekwencji adapterowych oraz selekcja odczytów o odpowiedniej jakości i długości

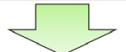

Usuwanie zanieczyszczeń (rRNA, niekodujące RNA)

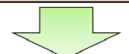

Przyrównanie do referencyjnego genomu lub transkryptomu z uwzględnieniem procesu splicingu

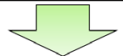

Wizualizacja danych

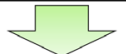

Pozycjonowanie rybosomu oraz określenie okresowości trzech nukleotydów

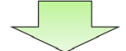

Określenie efektywności translacji

Rycina 4. Etapy analizy bioinformatycznej danych z profilowania rybosomów

należy się pozbyć [32]. Jest to etap bardzo istotny biorąc pod uwagę fakt, że pozostawienie sekwencji adapterowych doprowadza do błędów przy przyrównaniu sekwencji odczytów do genomu referencyjnego, jak również zwiększa liczbę odczytów nieprzyrównanych, ponieważ adaptery to syntetyczne sekwencje niewystępujące w sekwencji genomowej. Sekwencje adapterowe usuwa się w oparciu o oprogramowanie Cutadapt (https://cutadapt.readthedocs.io/ en/stable/index.html). Dalsza obróbka polega na usunięciu zbyt krótkich odczytów, pochodzących prawdopodobnie od nadtrawionych odcisków rybosomów [33]. Wśród otrzymanych odczytów znajdują się także sekwencje pochodzące od częściowo strawionego rRNA oraz tRNA, których również należy się pozbyć, aby nie zaburzały one kolejnych etapów analizy. W tym celu przyrównuje się sekwencje otrzymanych odczytów do sekwencji genomowych tRNA i rRNA badanego organizmu/kompartymentu. Aktualnie najczęściej wykorzystywanym do tego celu programem jest Bowtie2 (http://bowtie-bio.sourceforge.net/bowtie2/ index.shtml), pozwalający na szybkie i skuteczne przyrównanie sekwencji, które następnie zostają odrzucone [34].

\section{PRZYRÓWNANIE ODCZYTÓW DO GENOMU I TRANSKRYPTOMU}

Dopiero po filtracji i usunięciu zanieczyszczeń odczyty mogą zostać przyrównane do referencyjnego genomu lub transkryptomu za pomocą specjalistycznych programów wykorzystywanych z powodzeniem w analizach RNA-seq [35]. Biorąc pod uwagę fakt, że odciski rybosomów pochodzą z mRNA zazwyczaj przyrównywanie odczytów do transkryptomu jest wystarczające. Jednakże w przypadkach kiedy transkryptom nie jest dobrze scharakteryzowany zaleca się przyrównanie danych do genomu. Ze względu na fakt, że powstające podczas transkrypcji sekwencje mRNA 

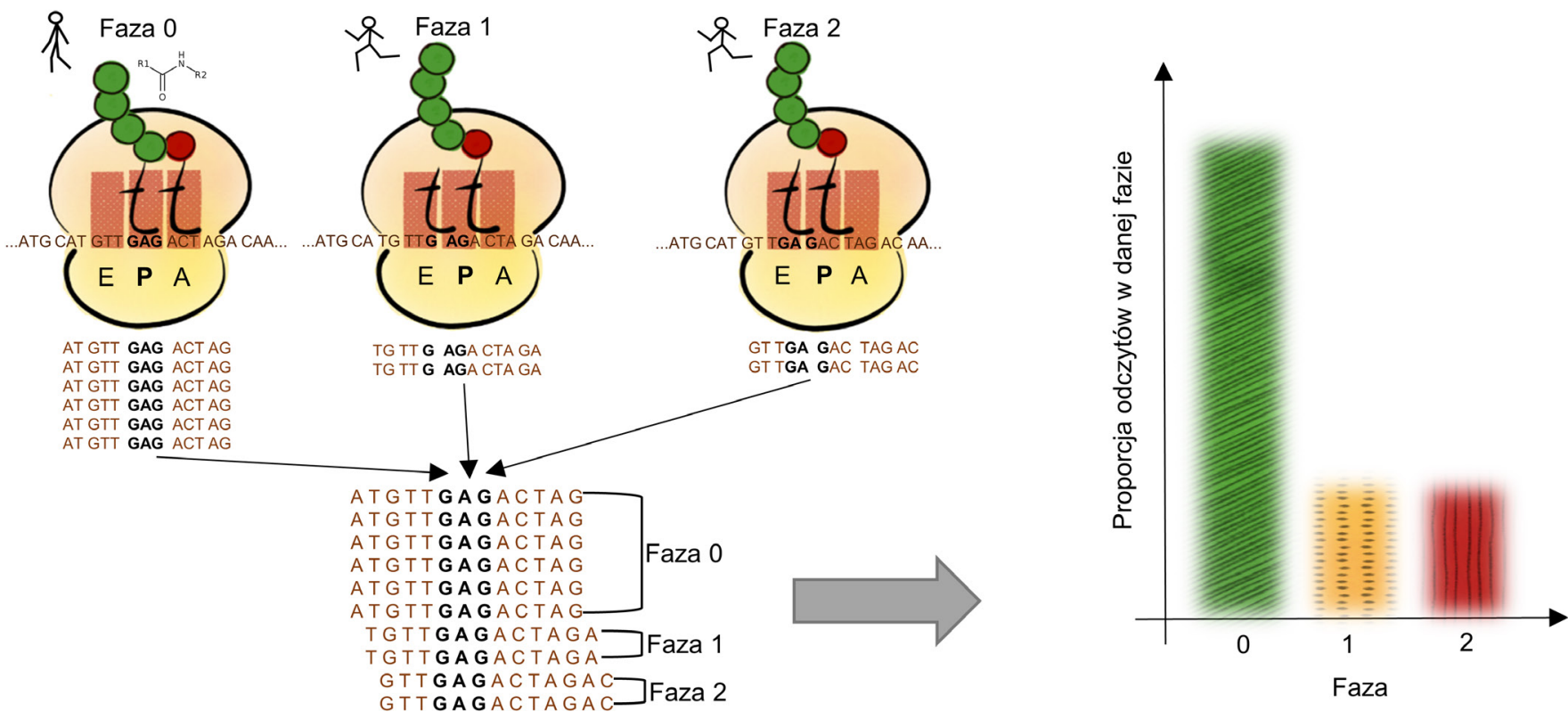

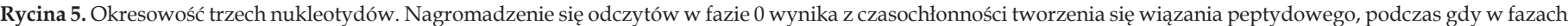
1 i 2 liczba odczytów jest znacznie mniejsza z uwagi na znacznie szybsze przesunięcia mRNA wewnątrz rybosomu.

ulegają wielu obróbkom potranskrypcyjnym prawidłowe przyrównanie sekwencji jest bardzo skomplikowane. Teoretycznie największy problem stanowią odczyty mapujące się na granicy egzonu i intronu, czyli w miejscach składania dojrzałego mRNA. Stąd też wiele współczesnych programów, tj. TopHat2 (http://ccb.jhu.edu/software/tophat) i STAR (http://code.google.com/p/rna-star/) podczas przyrównywania danych, nie tylko uwzględnia znane miejsca splicingu, ale również jest w stanie je przewidywać [36]. Kolejny problem mogą stanowić pojedyncze zmiany $\mathrm{w}$ sekwencji nukleotydowej $\mathrm{w}$ genomie oraz redagowanie RNA. W związku z tym parametry przyrównywania ustala się tak, aby program pozwalał na dopasowanie sekwencji odczytów do referencji z uwzględnieniem od jednego do trzech niedopasowań [37]. Poziom uwzględnionych przez program niedopasowań ustala się z reguły indywidualnie, biorąc pod uwagę rodzaj badanego genomu oraz transkryptomu. W przypadku przyrównania odczytów do transkryptomu mitochondrialnego Arabidopsis thaliana, charakteryzującego się wysokim stopniem edytowania, stosuje się mniej rygorystyczne warunki przyrównania, gdzie liczba stosowanych dozwolonych niedopasowań wzrasta do ok. 5 [38]. Otrzymane odczyty można wizualizować za pomocą programów: IGV (Integrative Genomics Viewer) (http://software.broadinstitute.org/software/igv/) lub IGB (Integrated Genome Browser) (https://bioviz.org/), pozwalających na interaktywne przeglądanie dużych, zintegrowanych danych genomowych.

\section{IDENTYFIKACJA AUTENTYCZNYCH ODCISKÓW RYBOSOMÓW}

Do tego etapu procedury odciski rybosomów identyfikowane są jedynie na podstawie ich wielkości oraz wiązania się z rybosomem. Aczkolwiek wśród wyselekcjonowanych fragmentów mogą znajdować się również fragmenty pochodzące od strukturalnych niekodujących RNA lub od frag- mentów RNA chronionych przez duże kompleksy rybonukleoproteinowe, które mogą ko-migrować z rybosomami podczas wirowania $\mathrm{w}$ gradiencie sacharozy na etapie izolacji frakcji monosomów [39]. Innym źródłem fałszywych odczytów, niepochodzących od odcisków rybosomów mogą być także fragmenty mRNA chronione przez białka wiążące RNA (RBPs, ang. RNA-binding proteins) [40].

Dowodem wskazującym, że uzyskane odczyty stanowią autentyczne odciski rybosomów jest ich nagromadzenie wzdłuż sekwencji kodujących (CDS, ang coding sequences) [41] oraz wykazywanie tzw. okresowości kodonów (okresowości trzech nukleotydów) (ang. 3-nt periodicity) [33,42]. Cecha ta wynika z dynamiki procesu translacji, gdzie podczas odczytywania kodu genetycznego najbardziej czasochłonne jest tworzenie wiązania pomiędzy aminoacylo-tRNA a rosnącym łańcuchem polipeptydowym, podczas gdy dalsze przesunięcie mRNA wewnątrz rybosomu, aby mógł zostać odczytany kolejny kodon, zachodzi już bardzo szybko (Ryc. 5). W rezultacie dochodzi do nagromadzenia odczytów mapujących się co trzy nukleotydy wzdłuż sekwencji kodującej. W prawidłowym określaniu okresowości kodonów translatujących rybosomów bardzo ważnym krokiem jest wyznaczenie miejsca peptydowego (miejsca P) rybosomu dla uzyskanych odcisków rybosomów $[43,44]$ (Ryc. 6). Pozycja ta wyznaczana jest dzięki określeniu odległości końca 5' i 3' odcisków rybosomów inicjujących (odczytujących kodon start) oraz kończących translację (odczytujących kodon stop) od miejsca $\mathrm{P}$, przesunięcie miejsca $\mathrm{P}$ względem odcisku rybosomalnego (PO, ang. P-site Offset). Typowo $\mathrm{PO}$ ustalone względem jednego z końców odcisków rybosomów 5' (5' PO, ang. 5'P-site Offset) lub 3' (3' PO, ang. $3^{\prime} P$ site Offset) jest stałe niezależnie od długości odcisku. Jednym z programów stosowanych do wyznaczenia przesunięcia miejsca P, który wykorzystuje zaawansowaną analizę bioinformatyczną, jest riboWaltz [43]. W porównaniu do istniejących narzędzi riboWaltz, korzystając z dwu- 


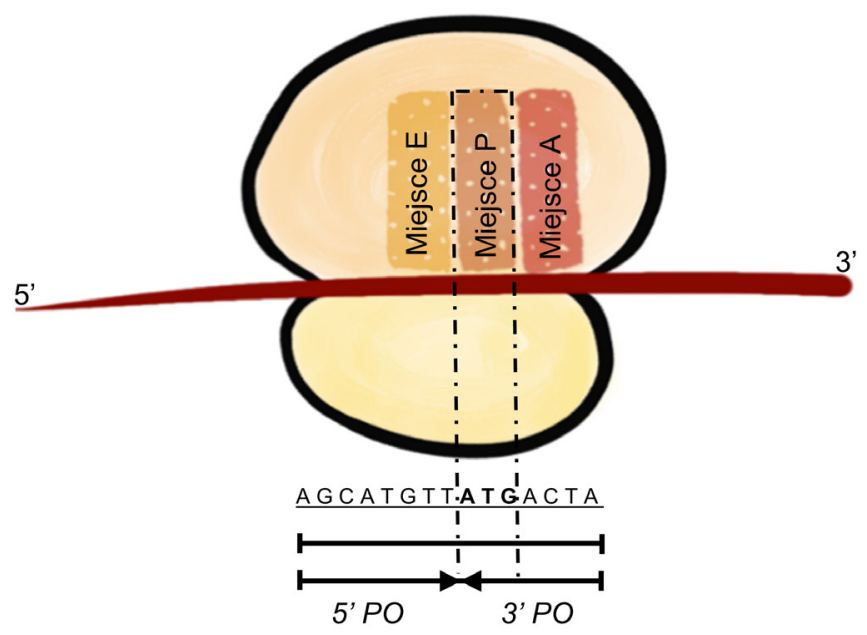

Rycina 6. Przesunięcie miejsca P rybosomu względem odcisku rybosomalnego. Przesunięcie miejsca P (PO) określane jest jako odległość końca 5' (5'PO) lub 3' $\left(3^{\prime} \mathrm{PO}\right)$ fragmentu chronionego przez rybosom od miejsca P. Rysunek opracowanowg [43]

etapowego algorytmu, oblicza z niezwykłą precyzją PO, wykazując przy tym większą dokładność i specyficzność w pozycjonowaniu miejsca P. Dopiero po odpowiednim spozycjonowaniu rybosomu możliwe jest określenie występowania okresowości kodonów, charakterystycznego dla translatujących rybosomów, za pomocą programów wykorzystujących odpowiednie algorytmy. W tym celu można skorzystać również z programu riboWaltz (https://github. com/LabTranslationalArchitectomics/riboWaltz) albo powszechnie znanego programu RiboTaper (https://ohlerlab. mdc-berlin.de/software/RiboTaper_126/).

\section{WYZNACZENIE PARAMETRÓW OKREŚLAJĄCYCH EFEKTYWNOŚĆ TRANSLACJI mRNA}

Efektywność translacji wyznacza się poprzez wyliczenie liczby odczytów przyrównanych do poszczególnych sekwencji CDS na podstawie danych pochodzących z analizy Ribo-seq i RNA-seq. Wybór programów służących do zliczenia zmapowanych odczytów jest dość szeroki i obejmuje: RSEM (https://github.com/deweylab/RSEM), featureCounts (http://bioinf.wehi.edu.au/featureCounts/), Cufflinks (http://cole-trapnell-lab.github.io/cufflinks/ manual/) oraz BEDTools (https://bedtools.readthedocs. io/en/latest/). Otrzymane dane są następnie wyrażane w postaci dwóch jednostek: RPKM (ang. Reads Per Kilobase Million) lub TPM (ang. Transcripts Per kilobase Million), dzięki którym możliwa jest normalizacja danych pod względem głębokości sekwencjonowania, jak również długości poszczególnych transkryptów [45]. Różnica między stosowanymi jednostkami wynika z kolejności wykonywania działań podczas normalizacji liczby zmapowanych odczytów. W przypadku RPKM dane najpierw normalizuje się względem głębokości sekwencjonowania, a dopiero później względem długości transkryptu, co sprawia, że suma znormalizowanych odczytów każdej biblioteki jest inna i w konsekwencji utrudnia to ich porównanie. Aktualnie zaleca się zastosowanie jednostki TPM, przy obliczaniu której najpierw normalizuje się odczyty względem długości transkryptu, a dopiero potem głębokości sekwen- cjonowania, przez co suma wszystkich znormalizowanych odczytów w każdej bibliotece jest taka sama. Taka normalizacja danych pozwala na porównywanie bibliotek różniących się między sobą liczbą odczytów. Na podstawie wyliczonych znormalizowanych odczytów uzyskanych w analizie Ribo-seq i RNA-seq wylicza się efektywność translacji (TE, ang. translation efficiency) poszczególnych transkryptów poprzez podzielenie wartości TPM dla Ribo-seq przez wartość TPM dla RNA-seq. Przy interpretacji uzyskanych w ten sposób danych należy jednak pamiętać, że gęstość odcisków rybosomów wzdłuż sekwencji kodującej odzwierciedla relatywny czas, w którym rybosom przebywa na danym kodonie, dlatego też należy zwrócić szczególną uwagę na profil odczytów wzdłuż sekwencji CDS. Nagromadzenie odcisków rybosomów w jednym miejscu może być spowodowane zastojem rybosomów, a nie być wynikiem zwiększonej efektywności translacji [7].

\section{WGLAD W PROCES SYNTEZY BIAŁEK I JEGO REGULACJĘ DZIĘKI ZASTOSOWANIU TECHNIKI PROFILOWANIA RYBOSOMÓW}

Profilowanie rybosomów dzięki możliwości określenia dokładnej pozycji oraz liczby rybosomów na transkrypcie stało się potężnym narzędziem umożliwiającym monitorowanie in vivo procesu translacji. Szczegółowa analiza rozkładu i liczby odcisków rybosomów może dostarczać informacji o zmianach w efektywności translacji białek, kinetyce poszczególnych etapów translacji oraz pozwalać na identyfikację nowych translatowanych ramek odczytu. Profilowanie rybosomów ułatwia także identyfikację i charakterystykę czynników wpływających na translację, jak również biorących udział w jej regulacji. W poniższych podrozdziałach zostały zebrane wybrane informacje bezpośrednio dotyczące procesu syntezy białek i jego regulacji otrzymane dzięki zastosowaniu techniki profilowania rybosomów.

\section{ISTNIENIE RÓŻNYCH KONFORMACJI TRANSLATUJĄCYCH RYBOSOMÓW}

Analiza rozkładu długości odcisków rybosomów wskazuje, że rybosomy nie zawsze pokrywają fragmenty mRNA o jednakowej długości. Za pomocą profilowania rybosomów wykazano u różnych organizmów, że rozkład długości odcisków rybosomów może być bimodalny [16,46,47]. Wykazano, że występowanie dwóch różnych populacji odcisków rybosomów (krótszych i dłuższych), charakteryzujących się porównywalną dystrybucją wzdłuż sekwencji kodujących oraz brakiem różnic w okresowości kodonów wynika $\mathrm{z}$ istnienia alternatywnych konfiguracji rybosomów [46,47]. Alternatywne stany konformacyjne odpowiadają różnym stanom elongacji, wymagającej strukturalnych rearanżacji rybosomu, w trakcie których dochodzi do obracania się podjednostek rybosomalnych względem siebie [46]. W konsekwencji tego procesu dłuższe odciski rybosomów pochodzą od nierotujących rybosomów podczas etapu dekodowania przed utworzeniem wiązania peptydowego, podczas gdy krótkie odciski pochodzą od rybosomów rotujących podczas etapu translokacji po utworzeniu wiązania peptydowego (Ryc. 7). Dodatkowo wykazano, że różne inhibitory elongacji translacji mogą stabilizować ryboso- 

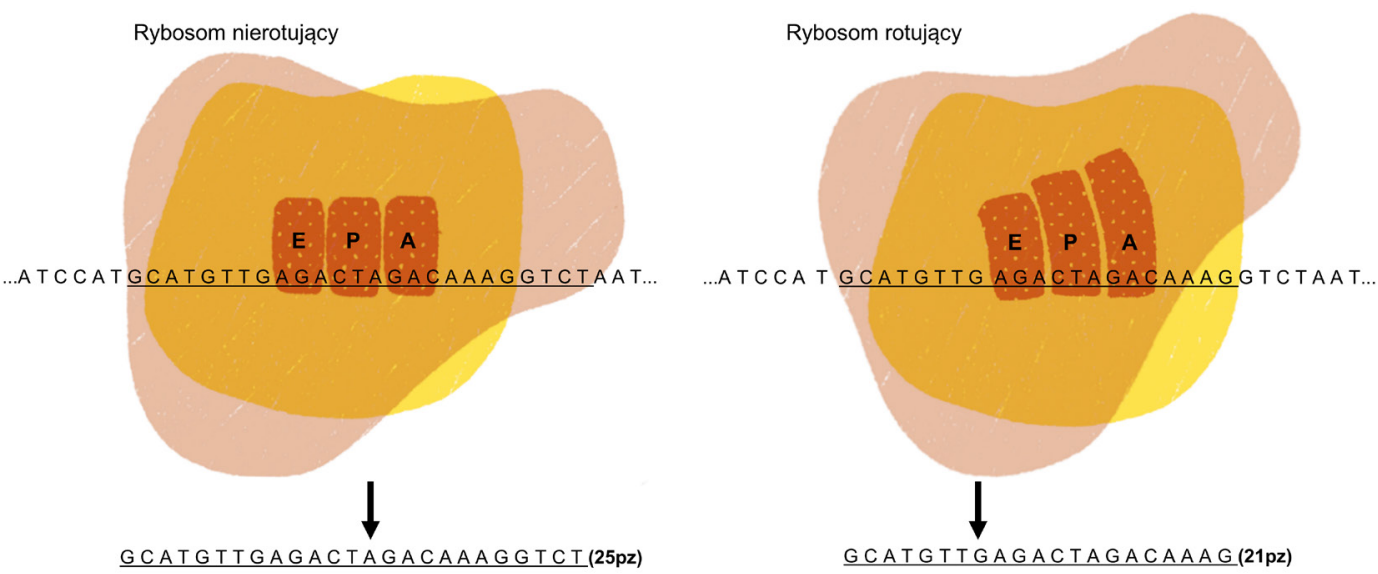

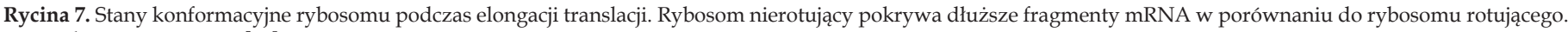
Rysunek opracowano wg [46]

my znajdujące się $\mathrm{w}$ różnych stanach konformacyjnych, co ma decydujący wpływ na rozkład długości odczytów uzyskiwanych $\mathrm{w}$ profilowaniu rybosomów. Co ciekawe pokazano również, że dystrybucja długości odczytów jest zróżnicowana w zależności od odczytywanych kodonów oraz szybkości translacji.

\section{HETEROGENNOŚĆ TRANSLATOMU}

Globalne badanie translacyjnej kontroli ekspresji genów wymaga precyzyjnego określenia miejsc inicjacji (TIS, ang translation initiation sites) oraz terminacji translacji (TTS, ang. translation termination sites). Według ogólnie przyjętego kanonu translacja u organizmów eukariotycznych rozpoczyna się od pierwszego kodonu AUG (kodon start) na mRNA i trwa aż do samego końca otwartej ramki odczytu, do napotkania przez rybosom kodonu stop [48]. Jednakże badania na komórkach drożdżowych i ssaczych, wykorzystujące profilowanie rybosomów, wskazują, że translacja może rozpoczynać się od alternatywnych kodonów start, innych niż kodon AUG, sugerując złożoność etapu inicjacji translacji $[18,26,33]$. Co ciekawe, u drożdży rozpoznawanie alternatywnych miejsc inicjacji translacji jest jednym z mechanizmów regulujących ekspresję genów podczas poszczególnych etapów mejozy [49]. Dane z profilowania rybosomów potwierdziły także dotychczasowe przypuszczenia, że kodon stop podczas terminacji translacji może zostać nierozpoznany przez rybosom, w związku z czym proces elongacji zachodzi dalej wykraczając poza ramkę odczytu $[33,40]$.

Profilowanie rybosomów okazało się przełomową metodą umożliwiającą identyfikację wszystkich zdarzeń translacyjnych na przestrzeni całego genomu. W szczególności umożliwia określenie, które krótkie otwarte ramki odczytu (ORF, ang. Open Reading Frames) ulegają translacji. Wśród nich najważniejszą grupę stanowią tzw. uORF (ang. upstream Open Reading Frame), które lokalizują się w 5' UTRach znanych transkryptów, występując przed lub nieco nachodząc na główne ramki odczytów tzw. mORF (ang. main Open Reading Frame) [7]. Translacji mogą ulegać także małe ORF (sORF, ang. small Open
Reading Frame), znajdujące się wewnątrz lub na końcu sekwencji kodującej właściwe białko. Zidentyfikowane za pomocą profilowania rybosomów uORFy i sORFy mogą brać udział w regulacji ekspresji genów. Wykazano, że ich aktywna translacja przeważnie prowadzi do spadku translacji głównej ramki odczytu (mORF) [27,49]. Ponadto analizy porównawcze Ribo-seq i RNA-seq, sugerują, że translacja małych ORF może wpływać na poziom mRNA w komórce, m.in. poprzez stymulację biogenezy tasi/ phasiRNA (ang. trans-acted/phased siRNA) zaangażowanych $\mathrm{w}$ wyciszanie transkryptów oraz obniżenie poziomu translacji mRNA [50]. Co więcej wzmożona translacja małych ORF koreluje ze spadkiem stabilności ich mRNA $[51,52]$. W tym przypadku najprawdopodobniej związane jest to $\mathrm{z}$ aktywnością szlaku NMD (ang. Nonsense-Mediated mRNA Decay), którego głównym zadaniem jest eliminacja mRNA zawierających przedwczesny kodon stop, co w konsekwencji zapobiega nagromadzeniu się nieprawidłowych produktów białkowych. Co ciekawe, okresowość kodonów, świadczącą o zachodzeniu procesu translacji, zaobserwowano także w obrębie długich niekodujących cząsteczek RNA (lncRNAs, ang. long non-coding RNAs) [53]. Jednakże powstające na ich matrycy polipeptydy są prawdopodobnie bardzo szybko degradowane, przez co poziom ich detekcji za pomocą spektrometrii mas jest bardzo niski. Przypuszcza się, że produkty degradacji tych polipeptydów mogą być źródłem antygenów wykorzystywanych przez układ immunologiczny [54].

Jeszcze innym źródłem heterogenności translatomu są powstające $\mathrm{w}$ komórkach różne izoformy tego samego białka [7]. Jak pokazały dotychczasowe badania wykorzystujące technikę profilowania rybosomów niektóre z nich mogą powstawać poprzez rozpoznawanie przez rybosom alternatywnych miejsc inicjacji translacji w obrębie tej samej sekwencji kodującej $[49,52]$ lub w wyniku translacji różnych form mRNA powstałych na drodze alternatywnego splicingu [55]. Istnienie izoform białek ma ogromne znaczenie biologiczne, biorąc pod uwagę fakt, że przeważnie charakteryzują się one odmienną funkcją, sposobem działania oraz mogą być kierowane do różnych kompartymentów komórki. 
CZYNNIKI WPEYWAJACEE NA SZYBKOŚĆ SYNTEZY BIAŁEK ORAZ ICH ZWIJANIE

Profilowanie rybosomów umożliwiając określenie szybkości z jaką zachodzi translacja wzdłuż sekwencji CDS, pozwala na badanie czynników, bądź zdarzeń wpływających na jej szybkość. Dzięki badaniom przeprowadzonym u bakterii i drożdży wykazano, że prędkość odczytywania kodonów nie koreluje z genomową preferencją kodonów, czyli częstotliwością wykorzystywania w komórce synonimicznych kodonów dla danego aminokwasu [56,57]. Prawdopodobnie jest to związane $\mathrm{z}$ równowagą pomiędzy poziomem danego tRNA a częstotliwością występowania odpowiadających mu kodonów. Potwierdzają to badania przeprowadzone na mysich embrionalnych komórkach macierzystych, które wykazały, że prędkość translacji zależy od adaptacji kodonów do puli tRNA znajdującego się w komórce. Dodatkowo za pomocą profilowania rybosomów wykazano, że do obniżenia szybkości translacji może dochodzić w wyniku lokalnych zmian w strukturze mRNA [58] oraz drgań powstających w wyniku parowania G-U podczas rozpoznawania kodonu [59].

Innym ważnym aspektem w kontekście prędkości syntezy białek, który może być badany za pomocą profilowania rybosomów, jest wpływ właściwości fizykochemicznych oraz struktury I i II rzędowej translatowanych białek. U bakterii oraz w komórkach ssaków pauzowanie rybosomów koreluje $\mathrm{z}$ występowaniem motywów bogatych $\mathrm{w}$ reszty proliny [60] oraz $\mathrm{w}$ reszty aminokwasów o ładunku dodatnim [61]. Jest to prawdopodobnie związane $\mathrm{z}$ utrudnionym wydostaniem się łańcucha polipeptydowego $\mathrm{z}$ kanału rybosomu. Reszty proliny powodują ograniczenie ruchu wiązania peptydowego, a reszty dodatnich aminokwasów oddziałują z resztami aminokwasów wewnątrz kanału rybosomu. Innymi przyczynami pauzowania rybosomów mogą być bardziej skomplikowane i idiosynkratyczne oddziaływania między powstającym peptydem a tunelem wyjściowym [62].

Nowo zsyntetyzowane białka aby prawidłowo funkcjonować w komórce muszą przyjąć wysoko zorganizowaną strukturę o charakterystycznej i stabilnej konformacji. W przypadku wielu białek proces ich fałdowania rozpoczyna się jeszcze podczas translacji, angażując sieć białek opiekuńczych [63]. Dzięki połączeniu techniki profilowania rybosomów z sieciowaniem białek oraz chromatografią powinowactwa możliwe jest monitorowanie momentu przyłączania się białek opiekuńczych do nowo powstającego polipeptydu. Zastosowanie takiego podejścia eksperymentalnego u E. coli wykazało, że TF (ang. Trigger Factor) wiąże się do rybosomów dopiero po syntezie około 100 aminokwasów, czyli w momencie wyłonienia się peptydu z kanału rybosomu, a nie wcześniej, jak to sugerowały badania in vitro [64]. Dodatkowo za pomocą profilowania rybosomów wykazano, że niektóre czynniki środowiskowe prowadzące do nieprawidłowego fałdowania się białek takie jak szok termiczny, stres oksydacyjny oraz związki chemicznie prowadzą do obniżenia poziomu syntezy białek poprzez zahamowanie elongacji $[11,65,66]$. Komórki drożdży i ssaków reagują na stres związany z fałdowaniem białek poprzez zatrzymanie translacji $\mathrm{w}$ obrębie pierwszych 30-60 kodonów. Zatrzymanie translacji następuje przeważnie kiedy powstający peptyd wyłania się $\mathrm{z}$ kanału rybosomu i może wchodzić $\mathrm{w}$ interakcje z białkami opiekuńczymi.

\section{UDZIAŁ CZĄSTECZEK RNA I BIAŁEK W KONTROLI TRANSLACJI}

Dane z profilowania rybosomów wnoszą istotne informacje na temat udziału różnych czynników trans w regulacji syntezy białek. Istnieje wiele doniesień mówiących o wpływie małych cząsteczek RNA, takich jak mikroRNA (miRNA) na proces translacji, jednakże dane dotyczące ich dokładnego działania nie są jednoznaczne. Profilowanie rybosomów przeprowadzone na ludzkich komórkach HeLa wykazało, że cząsteczki miRNA wpływają na ekspresję genów głównie poprzez degradację docelowego mRNA [67], podczas gdy u Danio pręgowanego (Danio rerio) pokazano, że miR-430 wpływa raczej na translację docelowego transkryptu [68]. Jeszcze inne analizy profilowania rybosomów przeprowadzone na różnych stadiach rozwojowych larw Caenorhabditis elegans sugerują, że cząsteczki miRNA mogą wpływać na ekspresję genów poprzez destabilizację mRNA, hamowanie inicjacji translacji oraz inne zdarzenia zaburzające etap elongacji translacji [15]. W ostatnich latach znaczny udział w stabilności i translacji mRNA przypisuje się długim niekodującym cząsteczkom RNA (lncRNAs). W korzeniach siewek Arabidopsis thaliana za pomocą profilowania rybosomów wykazano, że wiązanie się do rybosomów naturalnie występujących antysensownych traskryptów (NATs, ang. Natural Antisense Transcrips) do zwiększa stabilność oraz translację komplementarnych do nich mRNA [50].

Wspomniane powyżej niekodujące cząsteczki RNA mogą efektywnie kontrolować proces translacji głównie poprzez wiązanie się z mRNA na podstawie częściowej komplementarności par zasad. Jednakże, w ostatnich latach odkryto inną klasę niekodujących cząsteczek RNA zaangażowanych $\mathrm{w}$ regulację translacji, nazwaną rancRNAs (ang. ribosome associated non-coding RNAs) [69]. Źródłem tych cząsteczek są prekursorowe formy mRNA lub tRNA. Wykazano, że rancRNA bezpośrednio wiążą się z rybosomem, prowadząc do zahamowania translacji na poziomie globalnym poprzez konkurowanie z mRNA o wiązanie się do rybosomu [70]. Ostatnio zidentyfikowano rancRNA_s194, który poprzez interakcję z rybosomem hamuje tworzenie wiązania peptydowego i syntezę jednego z białek zaangażowanych w metabolizm cukrów u halobakterii Haloferax volcanii [71]. Jeszcze inny przykład udziału cząsteczek RNA w regulacji translacji został udokumentowany $\mathrm{w}$ badaniach porównawczych profilowania rybosomów oraz profilowania tRNA przeprowadzonych na przerzutowych komórkach raka piersi [72]. Pokazano, że wysoki poziom specyficznych cząsteczek tRNA promuje wzrost gęstości rybosomów wzdłuż sekwencji kodujących bogatych w kodony rozpoznawane przez dane tRNA, jednocześnie wpływając na stabilność ich mRNA.

Profilowanie rybosomów otwiera także nową drogę umożliwiającą badanie wpływu oraz sposobu działania 
białek na regulację procesu translacji. Dzięki zastosowaniu profilowania rybosomów dokonano charakterystyki szlaku sygnalnego związanego z regulacją procesu translacji przez kinazę mTOR u myszy i ludzi $[73,74]$. Kinaza mTOR okazała się globalnym regulatorem syntezy białek. Znaczna cześć transkryptów będących pod kontrolą kinazy mTOR zawiera przynajmniej jeden $\mathrm{z}$ dwóch charakterystycznych motywów bogatych $\mathrm{w}$ pirymidyny, tj. TOP (ang. 5'-Terminal Oligopyrimidine Tract) i PRTE (ang. Pyrimidine-Rich Translational Element) $[15,73,74]$. Ponadto analizy porównawcze profilowania rybosomów oraz spektrometrii mas pokazały, że peptydy powstające $w$ wyniku translacji ORF znajdujących się wewnątrz lncRNA mogą brać udział w regulacji translacji w konfiguracji trans [54]. Połączenie profilowania rybosomów z technikami badającymi interakcję białko - RNA pozwoliły na wykazanie, że LIN28A jest głównym inhibitorem translacji w siateczce endoplazmatycznej mysich embrionalnych komórek macierzystych [75]. Z kolei podobne analizy przeprowadzone u roślin pokazały, że $\mathrm{w}$ wyniku odpowiedzi immunologicznej białka wiążące ogony poli(A) promują translację mRNA poprzez oddziaływanie tych białek z motywami bogatymi w reszty purynowe znajdującymi się w regionach 5’UTR [76].

\section{PODSUMOWANIE}

Proces translacji jest jednym $\mathrm{z}$ końcowych etapów ekspresji genów, umożliwiającym organizmom szybkie dostosowanie się do zmieniających się warunków rozwojowych i środowiskowych. Profilowanie rybosomów nie tylko pozwala na identyfikację translatowanych rejonów genomu, monitorowanie szybkości translacji, ale umożliwia także badanie czynników wpływających na jej efektywność oraz badanie procesów jej towarzyszących. Chociaż dotychczasowe badania nie rozwiały wielu wątpliwości, wskazują jednoznacznie, że analizy porównawcze Ribo-seq i RNA-seq są potężnym narzędziem, które dostarczyło i z całą pewnością dostarczy w przyszłości wielu cennych informacji, które mogą zrewolucjonizować nasze spojrzenie na proces translacji.

\section{PIŚMIENNICTWO}

1. Xue S, Barna M (2012) Specialized ribosomes: a new frontier in gene regulation and organismal biology. Nat Rev Mol Cell Biol 13: 355-369

2. Filipovska A, Rackham O (2013) Specialization from synthesis: how ribosome diversity can customize protein function. FEBS Lett 587: 11891197

3. Kwasniak M, Majewski P, Skibior R, Adamowicz A, Czarna M, Sliwinska E, Janska H (2013) Silencing of the nuclear RPS10 gene encoding mitochondrial ribosomal protein alters translation in arabidopsis mitochondria. Plant Cell 25: 1855-1867

4. Segev N, Gerst JE (2018) Specialized ribosomes and specific ribosomal protein paralogs control translation of mitochondrial proteins. J Cell Biol 217: 117-126

5. Kervestin S, Amrani N (2004) Translational regulation of gene expression. Genome Biol 5: 359

6. Hershey JWB, Sonenberg N, Mathews MB (2012) Principles of translational control: An overview. Cold Spring Harb Perspect Biol 4: a011528

7. Ingolia NT (2014) Ribosome profiling: new views of translation, from single codons to genome scale. Nat Rev Genet15: 205-213

8. Pfeffer S, Lagos-Quintana M, Tuschl T (2005) Cloning of small RNA molecules. Curr Protoc Mol Biol Unit 26.4
9. Ingolia NT, Brar G a, Rouskin S, McGeachy AM, Weissman JS (2012) The ribosome profiling strategy for monitoring translation in vivo by deep sequencing of ribosome-protected mRNA fragments. Nat Protoc 7: 1534-1550

10. Hsu PY, Calviello L, Wu H-YL, Li F-W, Rothfels CJ, Ohler U, Benfey PN (2016) Super-resolution ribosome profiling reveals novel translation events in Arabidopsis. Proc Natl Acad Sci USA 113: E7126-E7135

11. Manuscript A, Magnitude S (2013) Co-translational response to proteotoxic stress by elongation pausing of ribosomes. Mol Cell 31: 17131723

12. Juntawong P, Girke T, Bazin J, Bailey-Serres J (2014) Translational dynamics revealed by genome-wide profiling of ribosome footprints in Arabidopsis. Proc Natl Acad Sci USA 111: E203-E212

13. Merchante C, Brumos J, Yun J, Hu Q, Spencer KR, Enríquez, Binder BM, Heber S, Stepanova AN, Alonso JM (2015) Gene-specific translation regulation mediated by the hormone-signaling molecule EIN2. Cell 163: 684-697

14. Brar GA, Weissman JS (2015) Ribosome profiling reveals the what, when, where and how of protein synthesis. Nat Rev Mol Cell Biol 16: 651-664

15. Michel AM, Baranov PV (2013) Ribosome profiling: a Hi-Def monitor for protein synthesis at the genome-wide scale. Wiley Interdiscip Rev RNA 4: 473-490

16. Chotewutmontri P, Barkan A (2016) Dynamics of chloroplast translation during chloroplast differentiation in maize. PLoS Genet 12: e1006106

17. Gerashchenko MV, Gladyshev VN (2014) Translation inhibitors cause abnormalities in ribosome profiling experiments. Nucleic Acids Res 42: e134

18. Lee S, Liu B, Lee S, Huang S-X, Shen B, Qian S-B (2012) Global mapping of translation initiation sites in mammalian cells at single-nucleotide resolution. Proc Natl Acad Sci USA 109: E2424-E2432

19. Fritsch C, Herrmann A, Nothnagel M, Szafranski K, Huse K, Schumann F, Schreiber S, Platzer M, Krawczak M, Hampe J, Brosch M (2012) Genome-wide search for novel human uORFs and N-terminal protein extensions using ribosomal footprinting. Genome Res 22: 22082218

20. Gerashchenko M V, Gladyshev VN (2017) Ribonuclease selection for ribosome profiling. Nucleic Acids Res 45: e6

21. Jelenc PC (1980) Rapid purification of highly active ribosomes from Escherichia coli. Anal Biochem 105: 369-374

22. Heiman M, Schaefer A, Gong S, Peterson JD, Day M, Ramsey KE, Suárez-Fariñas M, Schwarz C, Stephan DA, Surmeier DJ, Greengard P, Heintz N (2008) A Translational Profiling Approach for the Molecular Characterization of CNS Cell Types. Cell 135: 738-748

23. Sanz E, Yang L, Su T, Morris DR, McKnight GS, Amieux PS (2009) Cell-type-specific isolation of ribosome-associated mRNA from complex tissues. Proc Natl Acad Sci 106: 13939-13944

24. Petrova OE, Garcia-Alcalde F, Zampaloni C, Sauer K (2017) Comparative evaluation of rRNA depletion procedures for the improved analysis of bacterial biofilm and mixed pathogen culture transcriptomes. Sci Rep 7: 41114

25. Bhagwat AA, Ying ZI, Smith A (2014) Evaluation of ribosomal RNA removal protocols for for Salmonella RNA-Seq projects. Adv Microbiol 4: 25-32

26. Ingolia NT, Lareau LF, Weissman JS (2011) Ribosome profiling of mouse embryonic stem cells reveals the complexity and dynamics of mammalian proteomes. Cell 147: 789-802

27. Ingolia NT, Brar GA, Stern-Ginossar N, Harris MS, Talhouarne GJS, Jackson SE, Wills MR, Weissman JS (2014) Ribosome profiling reveals pervasive translation outside of annotated protein-coding genes. Cell Rep 8: 1365-1379

28. O'Connor PBF, Li GW, Weissman JS, Atkins JF, Baranov PV (2013) RRNA:mRNA pairing alters the length and the symmetry of mRNA-protected fragments in ribosome profiling experiments. Bioinformatics 29: 1488-1491 
29. Mohammad F, Woolstenhulme CJ, Green R, Buskirk AR (2016) Clarifying the translational pausing landscape in bacteria by ribosome profiling. Cell Rep 14: 686-694

30. Levin JZ, Yassour M, Adiconis X, Nusbaum C, Thompson DA, Friedman N, Gnirke A, Regev A (2010) Comprehensive comparative analysis of strand-specific RNA sequencing methods. Nat Methods 7: 709715

31. Illumina (2017) An introduction to next-generation sequencing technology. Dev Biol 276: 391-402

32. Didion JP, Martin M, Collins FS (2017) Atropos: specific, sensitive, and speedy trimming of sequencing reads. PeerJ 5: e3720

33. Ingolia NT, Ghaemmaghami S, Newman JRS, Weissman JS (2009) Genome-wide analysis in vivo of translation with nucleotide resolution using ribosome profiling. Science 324: 218-223

34. Petrova OE, Garcia-Alcalde F, Zampaloni C, Sauer K (2017) Comparative evaluation of rRNA depletion procedures for the improved analysis of bacterial biofilm and mixed pathogen culture transcriptomes. Sci Rep 7: 41114

35. Ingolia NT (2016) Ribosome footprint profiling of translation throughout the genome. Cell 165: 22-33

36. Dobin A, Davis CA, Schlesinger F, Drenkow J, Zaleski C, Jha S, Batut P, Chaisson M, Gingeras TR (2013) STAR: Ultrafast universal RNA-seq aligner. Bioinformatics 29: 15-21

37. Kim D, Pertea G, Trapnell C, Pimentel H, Kelley R, Salzberg SL (2013) TopHat2: accurate alignment of transcriptomes in the presence of insertions, deletions and gene fusions. Genome Biol 14: R36

38. Liang C, Cheng S, Zhang Y, Sun Y, Fernie AR, Kang K, Panagiotou G, Lo C, Lim BL (2016) Transcriptomic, proteomic and metabolic changes in Arabidopsis thaliana leaves after the onset of illumination. BMC Plant Biol 16: 43

39. Brar GA, Weissman JS (2015) Ribosome profiling reveals the what, when, where and how of protein synthesis. Nat Rev Mol Cell Biol 16: 651-664

40. Dunn JG, Foo CK, Belletier NG, Gavis ER, Weissman JS (2013) Ribosome profiling reveals pervasive and regulated stop codon readthrough in Drosophila melanogaster. Elife 2: e01179

41. Vasquez JJ, Hon CC, Vanselow JT, Schlosser A, Siegel TN (2014) Comparative ribosome profiling reveals extensive translational complexity in different Trypanosoma brucei life cycle stages. Nucleic Acids Res 42: 3623-3637

42. Calviello L, Mukherjee N, Wyler E, Zauber H, Hirsekorn A, Selbach M, Landthaler M, Obermayer B, Ohler U (2016) Detecting actively translated open reading frames in ribosome profiling data. Nat Methods 13: $165-170$

43. Lauria F, Tebaldi T, Bernabò P, Groen EJN, Gillingwater TH, Viero G (2018) riboWaltz: optimization of ribosome P-site positioning in ribosome profiling data. PLoS Comput Biol 14: e1006169

44. Irigoyen N, Firth AE, Jones JD, Chung BYW, Siddell SG, Brierley I (2016) High-resolution analysis of coronavirus gene expression by RNA sequencing and ribosome profiling. PLoS Pathog 12: e1005473

45. Wagner GP, Kin K, Lynch VJ (2012) Measurement of mRNA abundance using RNA-seq data: RPKM measure is inconsistent among samples. Theory Biosci 131: 281-285

46. Lareau LF, Hite DH, Hogan GJ, Brown PO (2014) Distinct stages of the translation elongation cycle revealed by sequencing ribosome-protected mRNA fragments. Elife 3: e01257

47. Rooijers K, Loayza-Puch F, Nijtmans LG, Agami R (2013) Ribosome profiling reveals features of normal and sdisease-associated mitochondrial translation. Nat Commun 4: 2886

48. Hinnebusch AG (2014) The scanning mechanism of eukaryotic translation initiation. Annu Rev Biochem 83: 779-812

49. Brar GA., Yassour M, Friedman N, Regev A, Ingolia NT, Weissman JS (2012) High-resolution view of the yeast meiotic program revealed by ribosome Profiling. Science 335: 552-557

50. Bazin J, Baerenfaller K, Gosai SJ, Gregory BD, Crespi M, Bailey-Serres J (2017) Global analysis of ribosome-associated noncoding RNAs unveils new modes of translational regulation. Proc Natl Acad Sci 114: E10018-E10027

51. Janich P, Arpat AB, Castelo-Szekely V, Lopes M, Gatfield D (2015) Ribosome profiling reveals the rhythmic liver translatome and circadian clock regulation by upstream open reading frames. Genome Res 25: 1848-1859

52. Arribere JA, Gilbert W V(2013) Roles for transcript leaders in translation and mRNA decay revealed by transcript leader sequencing. Genome Res 23: 977-987

53. Stern-Ginossar N, Weisburd B, Michalski A, Le VT, Hein MY, Huang SX, Ma M, Shen B, Qian SB, Hengel H, Mann M, Ingolia NT, Weissman JS (2012) Decoding human cytomegalovirus. Science 338: 1088-1093

54. Starck SR, Tsai JC, Chen K, Shodiya M, Wang L, Yahiro K, Martins-Green M, Shastri N, Walter P (2016) Translation from the 5' untranslated region shapes the integrated stress response. Science 351: aad3867

55. Michel AM, Choudhury KR, Firth AE, Ingolia NT, Atkins JF, Baranov PV (2012) Observation of dually decoded regions of the human genome using ribosome profiling data. Genome Res 22: 2219-2229

56. Li GW, Oh E, Weissman JS (2012) The anti-Shine-Dalgarno sequence drives translational pausing and codon choice in bacteria. Nature 484: 538-541

57. Qian W, Yang JR, Pearson NM, Maclean C, Zhang J (2012) Balanced codon usage optimizes eukaryotic translational efficiency. PLoS Genet 8: e1002603

58. Dana A, Tuller T (2012) Determinants of translation elongation speed and ribosomal profiling biases in mouse embryonic stem cells. PLoS Comput Biol 8: e1002755

59. Stadler M, Fire A (2011) Wobble base-pairing slows in vivo translation elongation in metazoans. RNA 17: 2063-2073

60. Woolstenhulme CJ, Parajuli S, Healey DW, Valverde DP, Petersen EN, Starosta AL, Guydosh NR, Johnson WE, Wilson DN, Buskirk AR (2013) Nascent peptides that block protein synthesis in bacteria. Proc Natl Acad Sci 110: E878-E887

61. Charneski CA, Hurst LD (2013) Positively charged residues are the major determinants of ribosomal velocity. PLoS Biol 11: e1001508

62. Navon SP, Kornberg G, Chen J, Schwartzman T, Tsai A, Puglisi EV, Puglisi JD, Adir N (2016) Amino acid sequence repertoire of the bacterial proteome and the occurrence of untranslatable sequences. Proc Natl Acad Sci USA 113: 7166-7170

63. Wruck F, Katranidis A, Nierhaus KH, Büldt G, Hegner M (2017) Translation and folding of single proteins in real time. Proc Natl Acad Sci USA 114: E4399-E4407

64. Oh E, Becker AH, Sandikci A, Huber D, Chaba R, Gloge F, Nichols RJ, Typas A, Gross CA, Kramer G, Weissman JS, Bukau B (2011) Selective ribosome profiling reveals the cotranslational chaperone action of trigger factor in vivo. Cell 147: 1295-1308

65. Shalgi R, Hurt JA, Krykbaeva I, Taipale M, Lindquist S, Burge CB (2013) Widespread regulation of translation by elongation pausing in heat shock. Mol Cell 49: 439-452

66. Gerashchenko M V, Lobanov A V, Gladyshev VN (2012) Genome-wide ribosome profiling reveals complex translational regulation in response to oxidative stress. Proc Natl Acad Sci USA 109: 17394-17399

67. Guo H, Ingolia NT, Weissman JS, Bartel DP (2010) Mammalian microRNAs predominantly act to decrease target mRNA levels. Nature 466: $835-840$

68. Bazzini AA, Lee MT, Giraldez AJ (2012) Ribosome profiling shows that miR-430 reduces translation before causing mRNA decay in Zebrafish. Science 336: 233-237

69. Pircher A, Gebetsberger J, Polacek N (2014) Ribosome-associated ncRNAs: An emerging class of translation regulators. RNA Biol11: 13351339

70. Gebetsberger J, Wyss L, Mleczko AM, Reuther J, Polacek N (2017) A tRNA-derived fragment competes with mRNA for ribosome binding and regulates translation during stress. RNA Biol 14: 1364-1373

71. Wyss L, Waser M, Gebetsberger J, Zywicki M, Polacek N (2018) mRNA-specific translation regulation by a ribosome-associated ncRNA in Haloferax volcanii. Sci Rep 8: 12502 
72. Goodarzi H, Nguyen HCB, Zhang S, Dill BD, Molina H, Tavazoie SF (2016) Modulated expression of specific tRNAs drives gene expression and cancer progression. Cell 165: 1416-1427

73. Hsieh AC, Liu Y, Edlind MP, Ingolia NT, Janes MR, Sher A, Shi E, Stumpf CR, Christensen C, Bonham MJ, Wang S, Ren P, Martin M, Jessen K, Feldman ME, Weissman JS, Shokat KM, Rommel C, Ruggero D (2012) The translational landscape of mTOR signalling steers cancer initiation and metastasis. Nature 485: 55-61
74. Thoreen CC, Chantranupong L, Keys HR, Wang T, Gray NS, Sabatini DM (2012) A unifying model for mTORC1-mediated regulation of mRNA translation. Nature 485: 109-113

75. Cho J, Chang H, Kwon SC, Kim B, Kim Y, Choe J, Ha M, Kim YK, Kim VN (2012) LIN28A is a suppressor of ER-associated translation in embryonic stem cells. Cell 151: 765-777

76. Xu G, Greene GH, Yoo H, Liu L, Marques J, Motley J, Dong X (2017) Global translational reprogramming is a fundamental layer of immune regulation in plants. Nature 545: 487-490

\section{Ribosome profiling as an innovative tool to study the process of protein synthesis}

\section{Urszula Kaźmierczak, Małgorzata Kwaśniak-Owczarek ${ }^{\varpi}$}

University of Wroclaw, Faculty of Biotechnology, 14A F. Joliot-Curie St., 50-383 Wroclaw, Poland

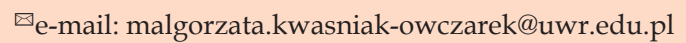

Key words: ribosome profiling, translation, ribosome, gene expression, next generation sequencing

\section{ABSTRACT}

The ribosome profiling approach (Ribo-seq) is currently the most effective method to study the protein synthesis in vivo. This technique relies on sequencing of ribosome protected mRNA fragments (so-called ribosomal footprints) allowing to indicate the exact positions of ribosomes on transcripts. Advanced bioinformatic analysis of Ribo-seq data enables selection of ribosomal footprints originated from translating ribosomes, providing information about authentic translational status of mRNA. Here, authors present principles of ribosome profiling method with special attention to basic experimental and bioinformatics strategies important for obtaining satisfactory results. Review includes examples of applications of ribosome profiling technique in various biological systems, giving the significant insight into the translation process and its regulation. 